\title{
A prospective review of renewable energy developments in
}

\section{Ethiopia [version 1; peer review: 1 approved, 1 approved with}

\section{reservations]}

\author{
Sameer Hameer (iD), Netsanet Ejigu² \\ ${ }^{1}$ School of Electrical and Electronic Engineering, Technical University of Kenya, Nairobi, Kenya \\ ${ }^{2}$ Bahir Dar Energy Research Centre, Bahir Dar University, Bahir Dar, Ethiopia
}

\author{
V1 First published: $14 \operatorname{Dec} 2020,3: 64$ \\ https://doi.org/10.12688/aasopenres.13181.1 \\ Latest published: $14 \mathrm{Dec} 2020,3: 64$ \\ https://doi.org/10.12688/aasopenres.13181.1
}

\section{Abstract}

Ethiopia has a vast renewable energy potential in the context of hydro, wind, solar, and geothermal energies. The unsustainable use of biomass coupled with drought has caused a paradigm shift towards wind, geothermal, and solar energies. There have been significant strides by the Government of Ethiopia to actualize these potentials in the context of developing massive projects in these aforementioned areas with the private business sector in the goal of jettisoning the industrial base of Ethiopia in conjunction with increasing the installed power capacity from 4,300 MW to $17,346 \mathrm{MW}$ by 2020 . The major challenge still lies in assessing the comprehensive renewable energy resource potential of Ethiopia including the lack of local content development in the context of establishing an industrial base. There have been notable initiatives by the Government of Ethiopia to adhere to the Paris Climate Accord in conjunction with the Green Growth framework and Sustainability Development Goals. However, the top down approach of grand targets to the various regions is not the pragmatic approach to solving the Achilles heel of energy poverty. A more plausible approach is from the bottom up, whereby energy frameworks and policies are generated by conducting a needs assessment of a specified region. The appropriate technology concept needs to be reflected in the innovation aspects of renewable energy technologies. There has to be a framework of translating invention to innovation by actualizing the tripartite structure of Government, Academia, and Industry.

Keywords

Ethiopia, Energy, Geothermal, Wind, Hydro, Solar, Biogas, Biomass

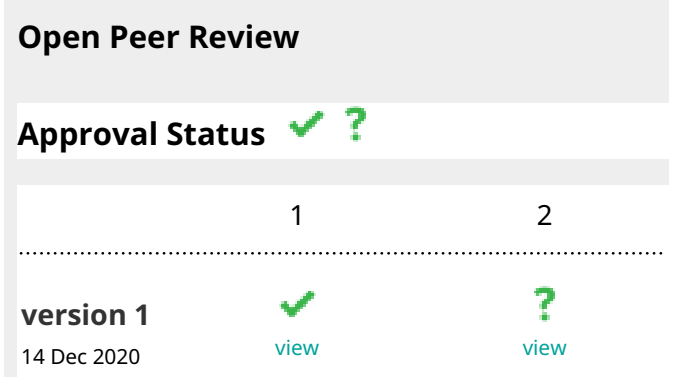

1. David Ajene Alemzero, Jiangsu University,

Zhenjiang, China

2. Muhammad Shahzad Nazir (iD), Huaiyin

Institute of Technology, Huai'an, China

Any reports and responses or comments on the article can be found at the end of the article. 


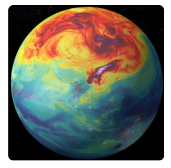

This article is included in the Climate collection.

Corresponding author: Sameer Hameer (sameer.hameer@tukenya.ac.ke)

Author roles: Hameer S: Conceptualization, Formal Analysis, Investigation, Methodology, Resources; Ejigu N: Investigation, Methodology, Validation, Writing - Review \& Editing

Competing interests: No competing interests were disclosed.

Grant information: No grant was provided for this research work. Prof Sameer Hameer is an Affiliate of the African Academy of Sciences.

The funders had no role in study design, data collection and analysis, decision to publish, or preparation of the manuscript.

Copyright: $\odot 2020$ Hameer S and Ejigu N. This is an open access article distributed under the terms of the Creative Commons Attribution License, which permits unrestricted use, distribution, and reproduction in any medium, provided the original work is properly cited.

How to cite this article: Hameer S and Ejigu N. A prospective review of renewable energy developments in Ethiopia [version 1; peer review: 1 approved, 1 approved with reservations] AAS Open Research 2020, 3:64 https://doi.org/10.12688/aasopenres.13181.1

First published: 14 Dec 2020, 3:64 https://doi.org/10.12688/aasopenres.13181.1 


\section{Introduction}

Energy is the key input in economic growth and there is a close link between the availability of energy and the growth of a nation. Energy is essential to conduct the process of production that requires higher energy consumption in the context of economic development. Ethiopia's energy consumption is predominantly based on overutilization of biomass energy sources in conjunction with a low rural electrification rate of $5 \%$ and urban electrification rate of 25\% (MOWIE, 2012). An overwhelming proportion of $94 \%$ of the country's energy demand is met by traditional energy sources such as fuel wood, charcoal, branches, dung cakes and agricultural residues in an unsustainable manner (MOWIE, 2012). The balance is met by commercial energy sources such as electricity and petroleum. The most important issue in the energy sector is the supply of household fuels, which is associated with massive deforestation and the resultant land degradation. The increasing scarcity of fuel wood is compounded by Ethiopia's high population growth rate of $2.3 \%$ (Bekele, 2017). The average annual GDP growth rate is approximately $10 \%$ (Bekele, 2017).

The potential scaling-up of renewable energy program (SREP) investments have been prioritized in accordance with assisting the Government of Ethiopia in meeting the overall demand for energy and improve access to energy at international standards, as per the growth and transformation plan (GTP), while adhering to the low-carbon mission statement of the climate resilient green economy (CRGE) and addressing the broader structural concerns regarding energy access and productive energy use for rural communities.

The GTP II, which has been implemented as of September 2017, emphasizes some of the major energy goals:

$>$ increase power generation capacity from 2,000 MW to $10,000 \mathrm{MW}$;

$>$ increase grid access from $41 \%$ to $75 \%$ of the population;

$>$ double grid connections from 2 million to 4 million households;

$>$ increase households supplied with at least one kind of modern, efficient and renewable energy source/ technology from $16 \%$ to $80 \%$;

$>\quad$ electrify more than 1,500 towns/villages per year'

$>$ disseminate more than 3 million solar lanterns and solar home systems in tandem with 9 million efficient cook stove with the assistance of development partners'

Ethiopia is endowed with vast energy resources, namely hydro, solar, wind, geothermal, biomass, natural gas. The major challenge is that Ethiopia has not been able to develop, transform and utilize these resources for optimal economic development (MOWIE, 2012). Therefore, the Government of Ethiopia believes it is imperative to provide the economy with the necessary energy inputs at the right time and affordable prices. This will speed economic development and help the country attain the objectives of the economic reform program the Government has adopted (MOWIE, 2012). The formulation of a comprehensive national energy policy is vital in the development of an energization plan for Ethiopia.

The Government of Ethiopia has recently initiated a 1000 MW geothermal project in the areas of Tulu Moye and Corbetti. Additionally, the Government of Ethiopia in cooperation with investors has built the first waste to energy plant in Ethiopia with an installed capacity of $50 \mathrm{MW}$, which will be fully operational in 2018. The Government of Ethiopia also intends to be the wind power capital by 2020 by increasing the wind installed capacity to $5,200 \mathrm{MW}$ in addition to being the fifth largest investor in renewable energies that is valued at US $\$ 100$ million. Enel Green Power is also intending to build a $100 \mathrm{MW}$ solar park in Ethiopia, which is valued at US\$120 million. The Government of Ethiopia intends to build three solar parks with a combined capacity of 300 MW in Semera, Awash Arba, and Afar regional state. There have also been techno-economic studies of renewable energy technologies conducted in the rural part of the Tigray region in Ethiopia (Gezahegn et al., 2018). The master plans of wind and solar energy for Ethiopia have been developed (Jiangtao et al., 2012). There have been incentives by the Ethiopian Government in the development of the Fuelwood-Efficient Stoves Investment Plan (MOWIE, 2012-2015).

\section{The current energy situation in Ethiopia}

The current installed grid capacity of Ethiopia is 4,284 MW (Bekele, 2017). The generation accounting for wind energy, hydro power, geothermal energy, and diesel is shown in Figure 1. Ethiopia has a hydro power potential of $46 \mathrm{GW}$; geothermal energy potential of $10 \mathrm{GW}$; and wind energy potential of $1000 \mathrm{GW}$ at $50 \mathrm{~m}$ height (Bekele, 2017). However, the current installed grid capacity is underutilized and requires a systematic resource management plan. The geographic access to the grid is about $56 \%$ with a household connectivity of $25 \%$ (Bekele, 2017). Ethiopia's annual per capita electricity consumption is $100 \mathrm{kWh}$ in conjunction with a low densification rate (Bekele, 2017). The existing plants that are connected to the national grid are shown in Table 1, including future power plants. The location of the hydropower dams in the form of a GIS map are shown in Figure 2 (Bekele, 2017). The future works include the $62 \%$ completed Grand Ethiopian Renaissance Dam with an installed capacity of 6000 MW (Bekele, 2017). The primary

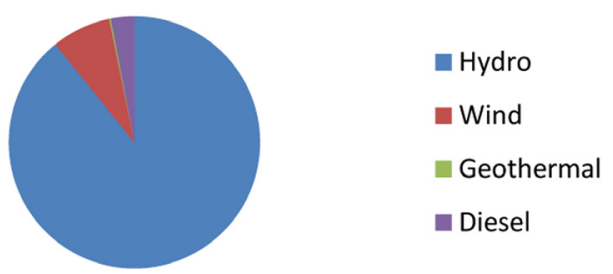

Figure 1. Installed capacity of the Ethiopian grid. 
Table 1. Existing plants capacity connected to the national grid in MW (Bekele, 2017).

\begin{tabular}{|c|c|c|c|c|c|c|}
\hline Power Plant & Hydro & Diesel & Geothermal & Wind & Total & In-Service date \\
\hline Koka & 43.2 & & & & 43.2 & 1960 \\
\hline Awash II & 32 & & & & 32 & 1966 \\
\hline Awash III & 32 & & & & 32 & 1971 \\
\hline Finchaa & 134 & & & & 134 & $1973 / 2003$ \\
\hline Meleka Wakena & 153 & & & & 153 & \\
\hline Tis Abay I & 11.4 & & & & 11.4 & 1964 \\
\hline Tis Abay II & 73 & & & & 73 & 2001 \\
\hline Gilbel Gibe & 184 & & & & 184 & 2004 \\
\hline Aluto Langano & & & 7.3 & & 7.3 & 1999 \\
\hline Kaliti & & 14 & & & 14 & 2004 \\
\hline Dire Dawa & & 38 & & & 38 & 2004 \\
\hline Awash 7 Killo & & 35 & & & 35 & 2004 \\
\hline Tekeze & 300 & & & & 300 & Oct 2009 \\
\hline Gilgel Gibe II & 420 & & & & 420 & Jan 2010 \\
\hline Beles & 460 & & & & 460 & May 2010 \\
\hline $\begin{array}{l}\text { Fincha Amerti } \\
\text { Neshi }\end{array}$ & 97 & & & & 97 & Aug 2011 \\
\hline Ashegoda & & & & 120 & 120 & Jan 2012 \\
\hline Adama I & & & & 51 & 51 & March 2010 \\
\hline Adama II & & & & 153 & 153 & May 2015 \\
\hline Gibe III & 1870 & & & & & July 2015 \\
\hline Assela & & & & 100 & & Under Development \\
\hline Aysha & & & & 300 & & Under Development \\
\hline Debre Berhan & & & & 100 & & Under Development \\
\hline Adama 3 & & & & 150 & & Under Development \\
\hline Mossobo & & & & 42 & & Under Development \\
\hline
\end{tabular}

energy production of Ethiopia is shown in Figure 3 (Buzanakova, 2015).

Figure 4 shows the various power plants connected to the national grid, with hydro power being the dominant power source, as substantiated by the fact that Ethiopia is a mountainous region. The self-sufficiency of Ethiopia based on energy imports is shown in Figure 5 (WDI, 2014)

The current electricity demand forecast for the various sectors are shown in Figure 6 (Bekele, 2017). Figure 6 shows the increase in electricity demand for the Universal Electricity Access Expansion Program (UAEP), irrigation, transport, new industry and commercial sectors from the year 2012 to 2033. The electricity generation plan is shown in Figure 7 (Bekele, 2017). Figure 7 shows the increased use of hydro, geothermal, and wind energies up to the year 2037 compounded with a very small proportion of solar energy in the mix. Ethiopia needs to incorporate solar energy in the mix, as Ethiopia has an excess of $5.5 \mathrm{kWh} / \mathrm{m}^{2} /$ day global horizontal irradiance $(\mathrm{GHI})$ potential (Bekele, 2017).

Figure 8 shows the load forecasts of the transport, agriculture, industrial, and service sectors (Bekele, 2017). The industrial sector has the highest load forecast as expected followed by the agriculture, service, and transport sectors. 


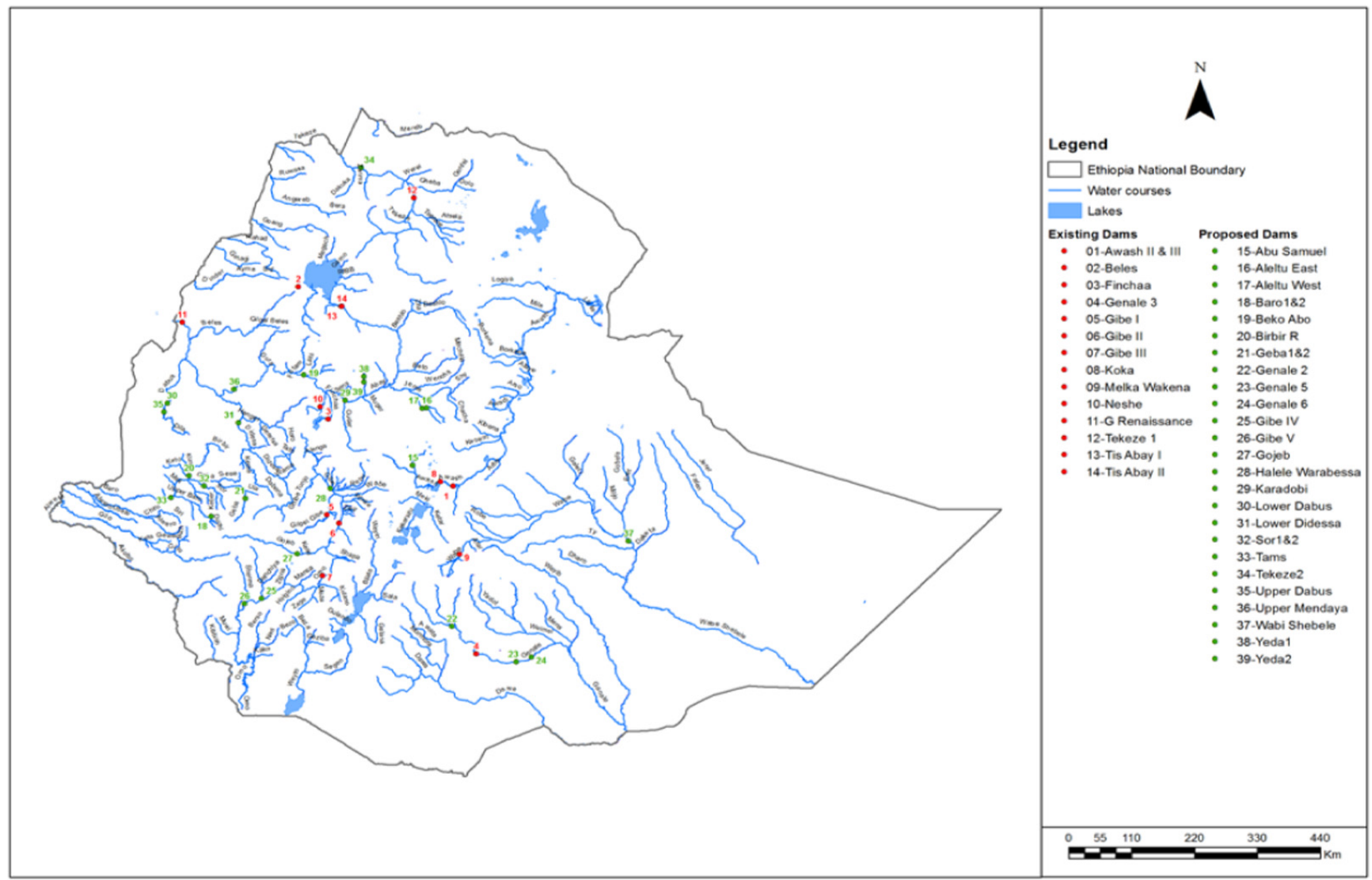

Figure 2. Location of existing and proposed dams (reproduced with permission of Bekele, 2017).

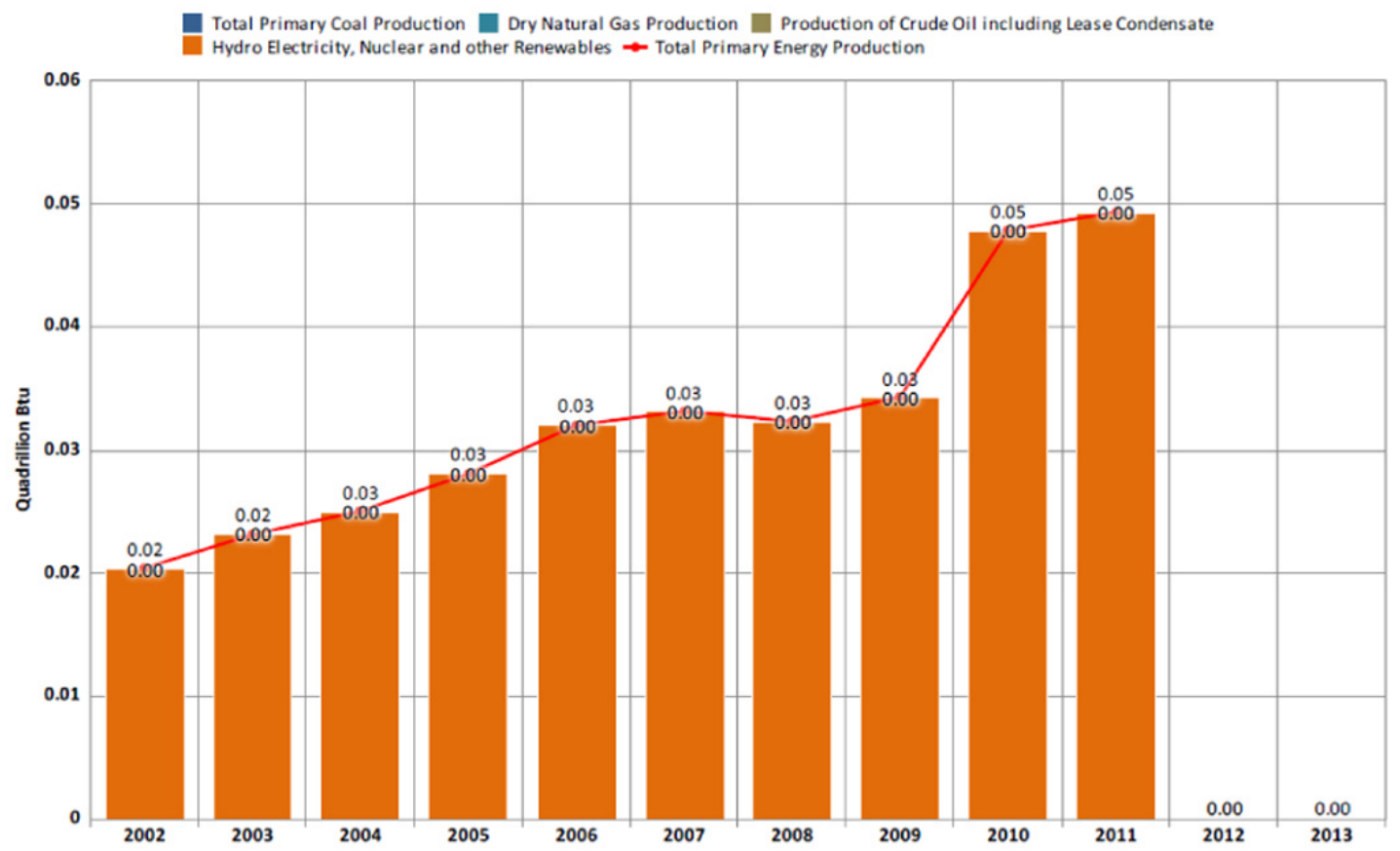

Figure 3. Ethiopia's energy production (reproduced with permission of Buzanakova, 2015). 


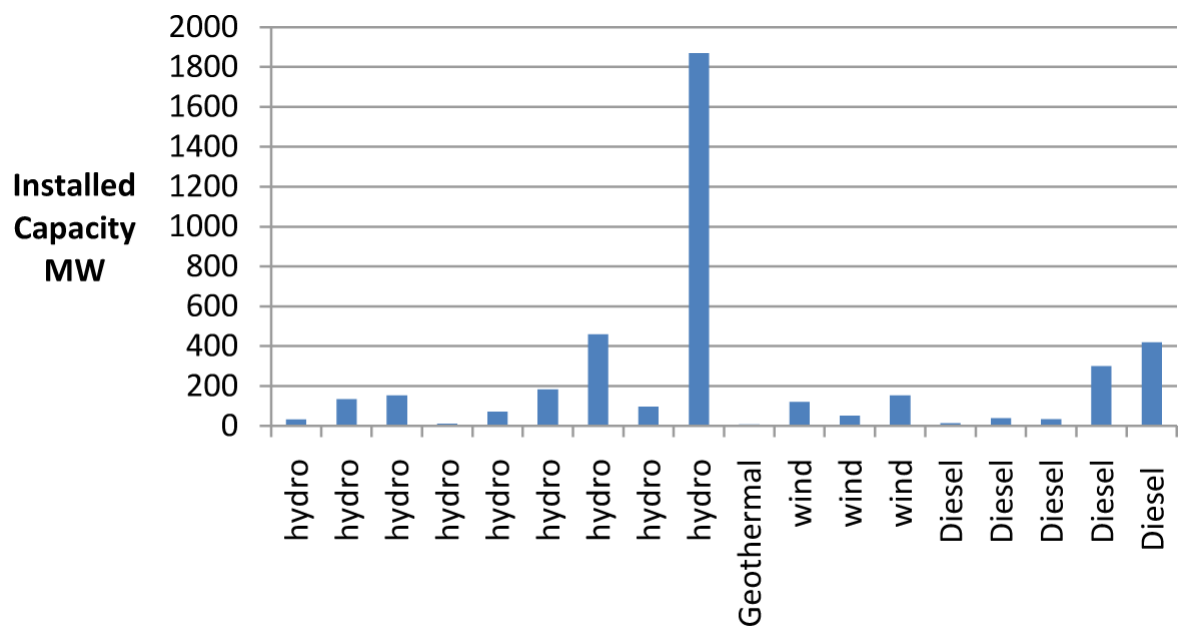

Power Plants

Figure 4. Capacities of the various power plants.

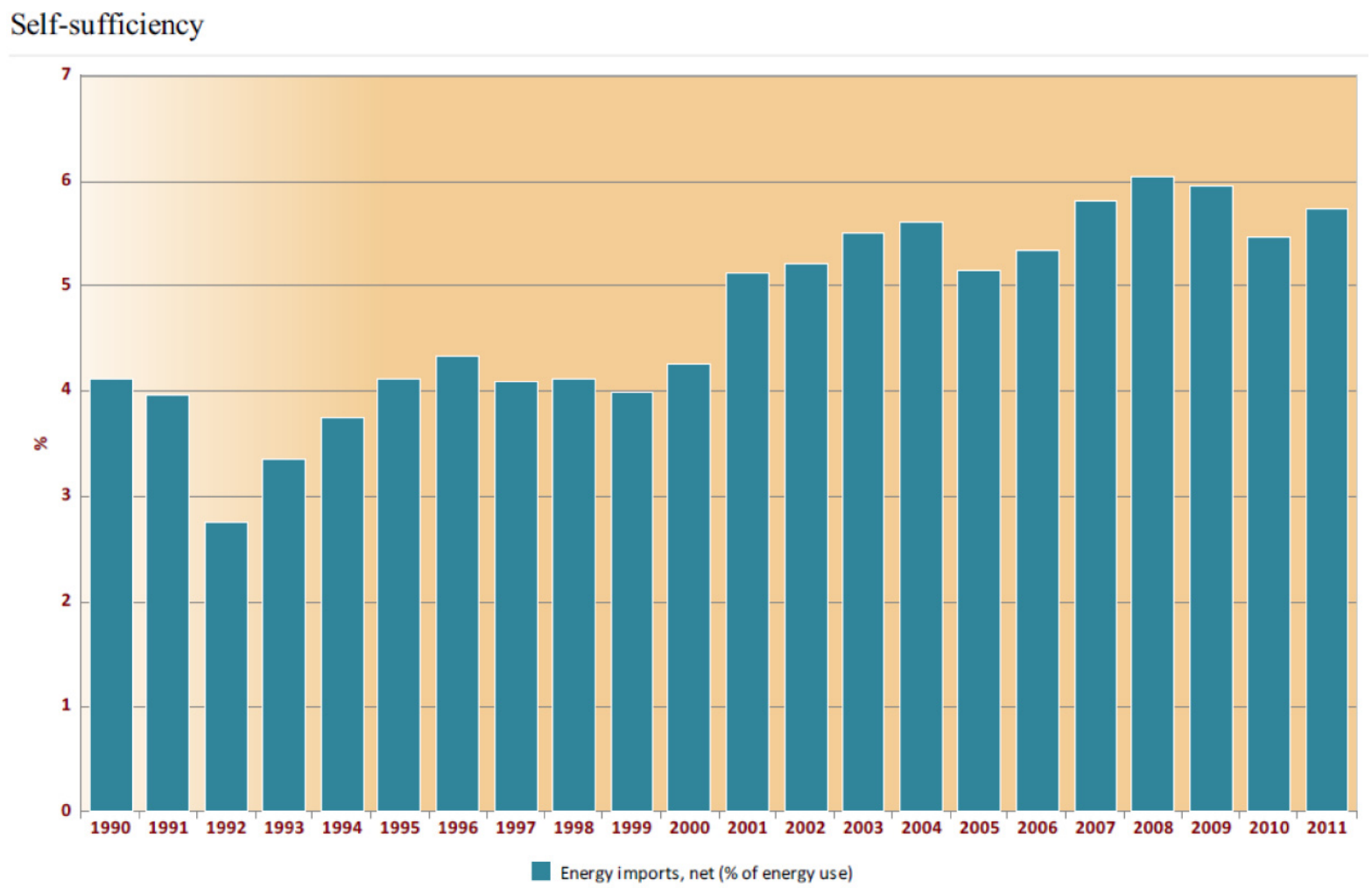

Figure 5. Self-sufficiency of Ethiopia (reproduced with permission of WDI, 2014).

\section{Renewable energy trends in Ethiopia}

\section{Solar energy}

Ethiopia's solar photovoltaic potential is shown in Figure 9. The areas that are favorable are to the north, north-west, and eastern regions of the country including a few locations in the south. Ethiopia has a favorable GHI in the northern and eastern regions of the country, as depicted in Figure 10. The relatively high GHI potential of Ethiopia makes it ideal for photovoltaics, solar water heaters and non-concentrating solar power systems implementation in general. On the contrary, Ethiopia is 


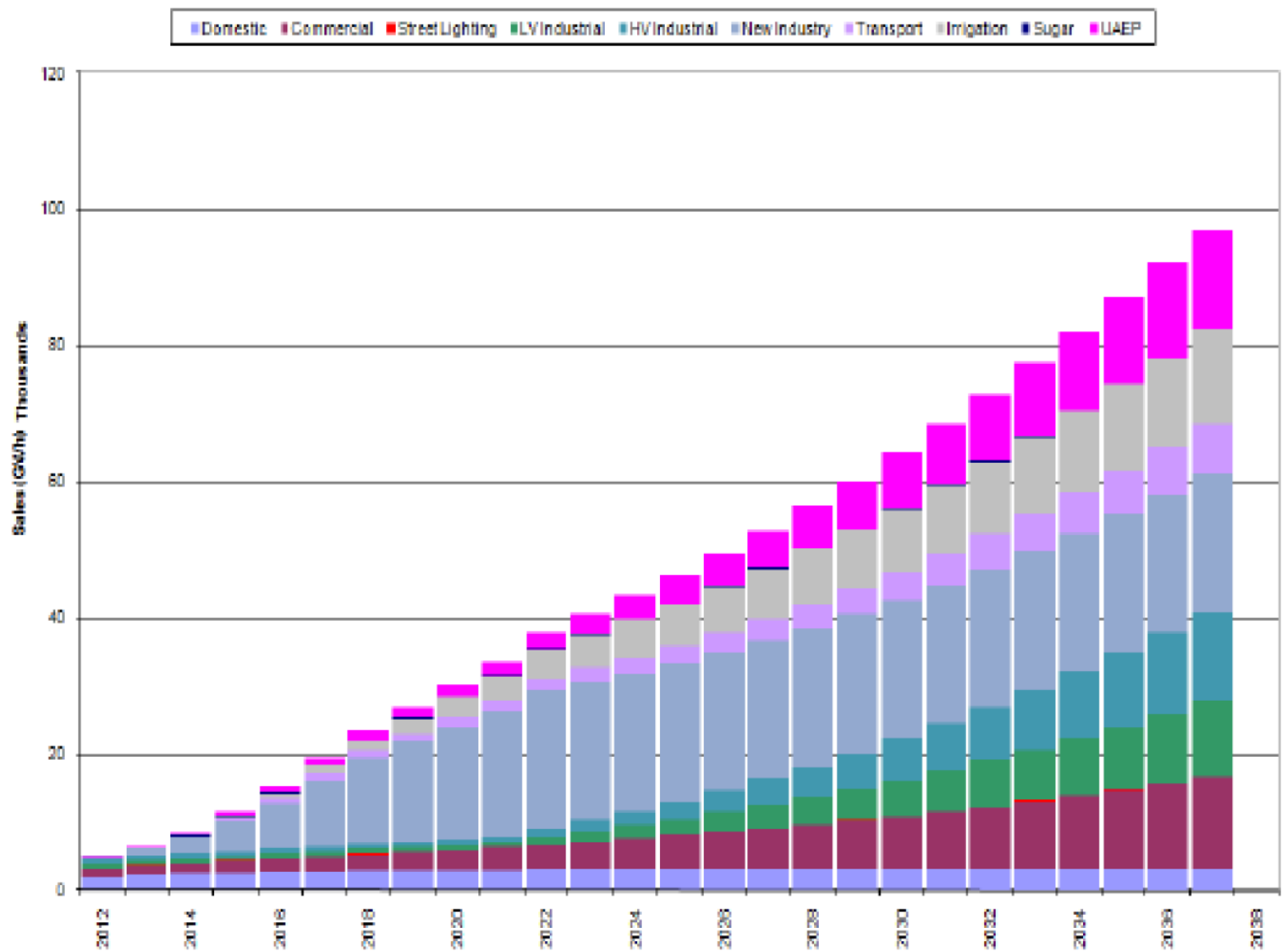

Figure 6. Electricity demand forecast (reproduced with permission of Bekele, 2017).

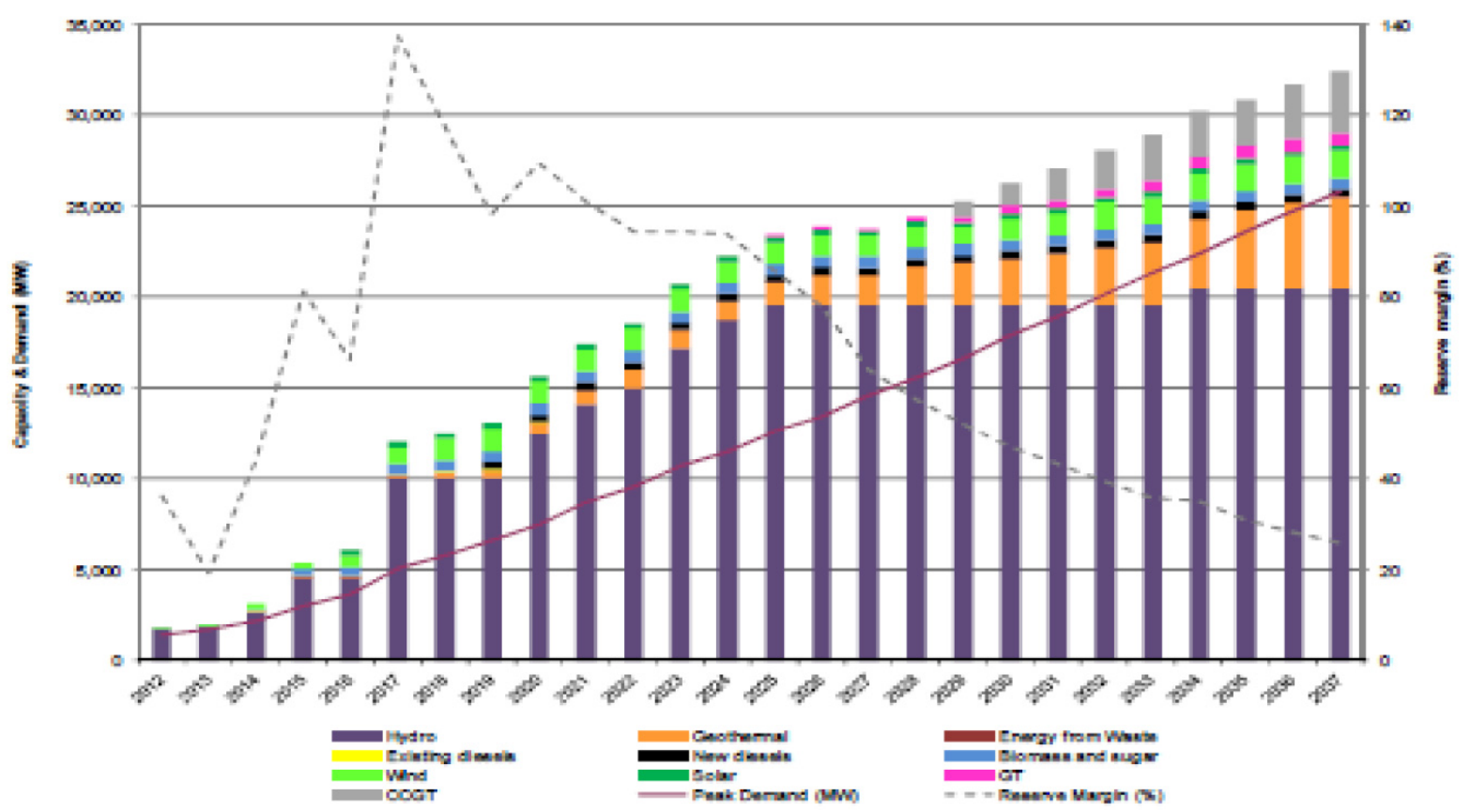

Figure 7. Electricity Generation Plan (reproduced with permission of Bekele, 2017). 
Transport Sector Load Forecast

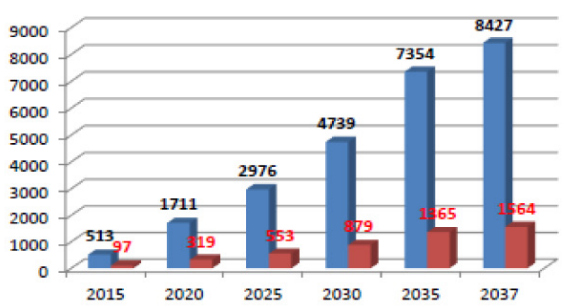

Industrial Sector Load Forecaste

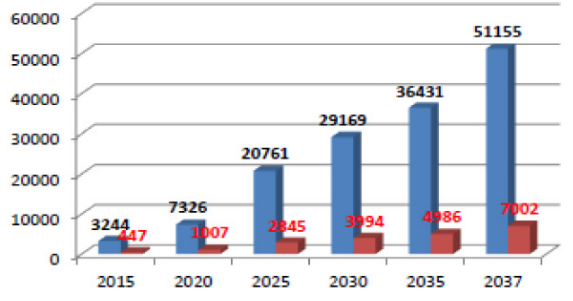

Agriculture Sector Load Forecaste

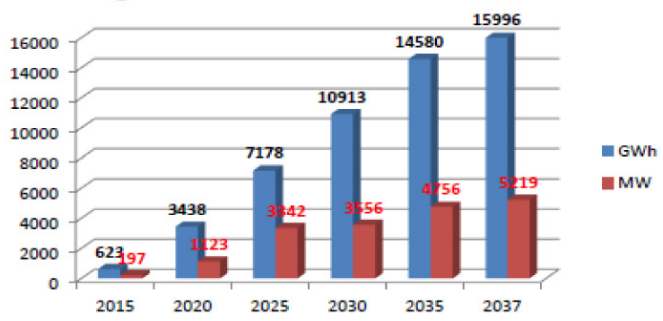

Service Sector Load Forecaste

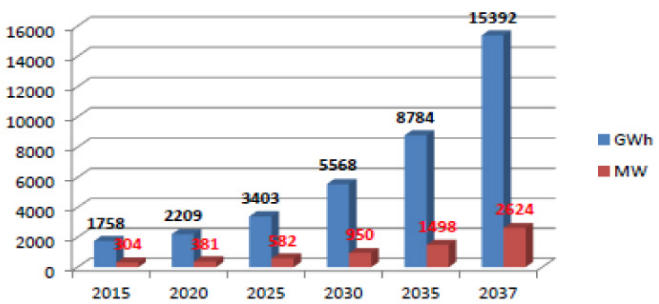

Figure 8. Load forecasts for the various sectors (reproduced with permission of Bekele, 2017).

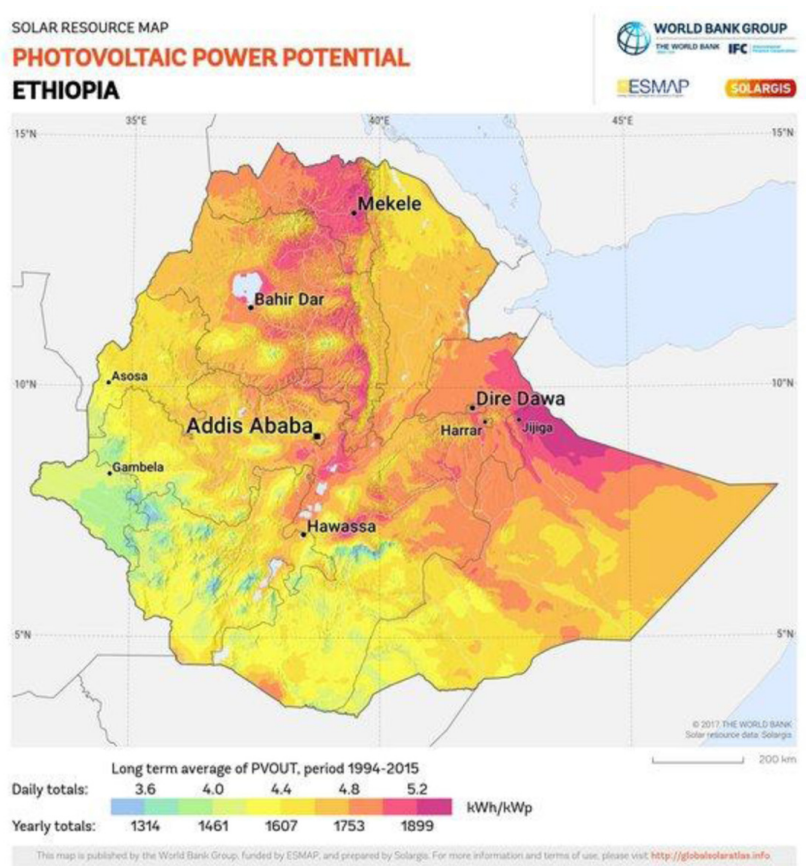

Figure 9. Solar photovoltaic potential of Ethiopia (reproduced with permission; copyright SOLARGIS) (GeoModel Solar).

not favorable for concentrating solar power (CSP) as the favorable DNI is restricted to very few places in the north and at the border with Somalia in the east, as shown in Figure 11. The lack of availability of water and lack of access to the grid in these areas compounded with dilapidated infrastructure hinders CSP development in Ethiopia.

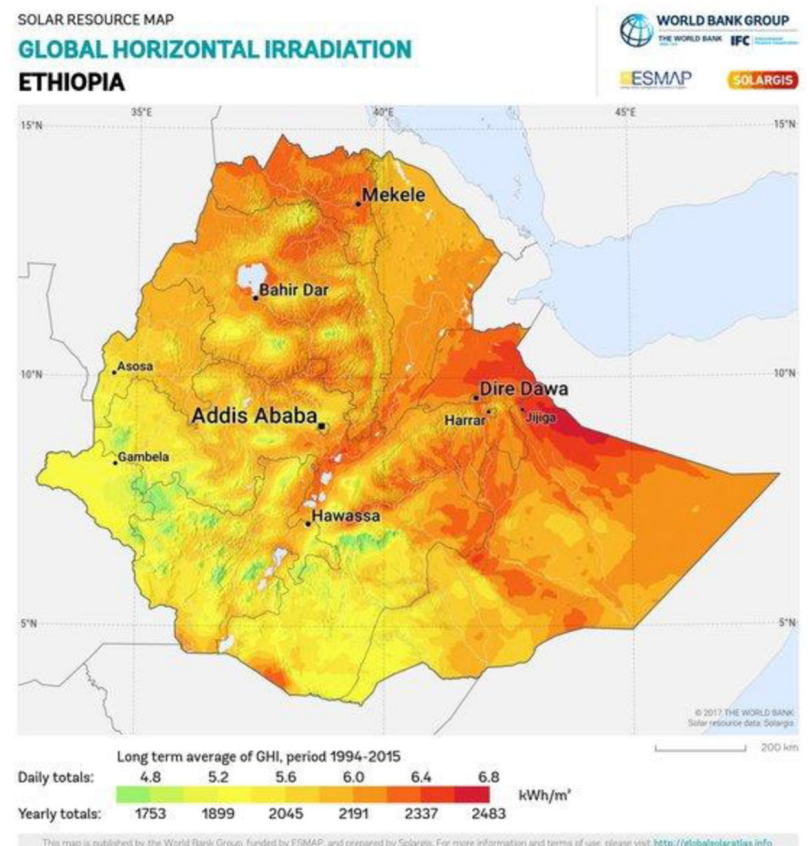

Figure 10. GHI potential of Ethiopia (reproduced with permission; copyright SOLARGIS) (GeoModel Solar).

The solar PV capacity installed in Ethiopia for the various sectors in the year 2011 is shown in Figure 12 (ISEI, 2012).

There have been several notable researches conducted on solar resource assessment in Ethiopia in conjunction with the application of solar energy for powering rural communities in the 
context of hybrid systems, as substantiated below in the solar resource assessment conducted in the Geba catchment area, which has an average GHI potential of $5.59 \mathrm{kWh} / \mathrm{m}^{2} /$ day. This favorable GHI potential posits an opportunity of using the village as a power park concept for the rural communities (Mahmud et al., 2014). In addition, the Geba catchment has potential for large scale concentrating solar power systems to be implemented (Mahmud et al., 2014). There have also been studies on developing detailed solar energy maps for Ethiopia (Mekonnen, 2007).

There have been studies focusing on solar PV grid connectivity aspects in the context of assessing the techno-economic viability of a 5 MW Solar PV grid connected system for 35 locations in Ethiopia (Kebede, 2017). In addition, there have been

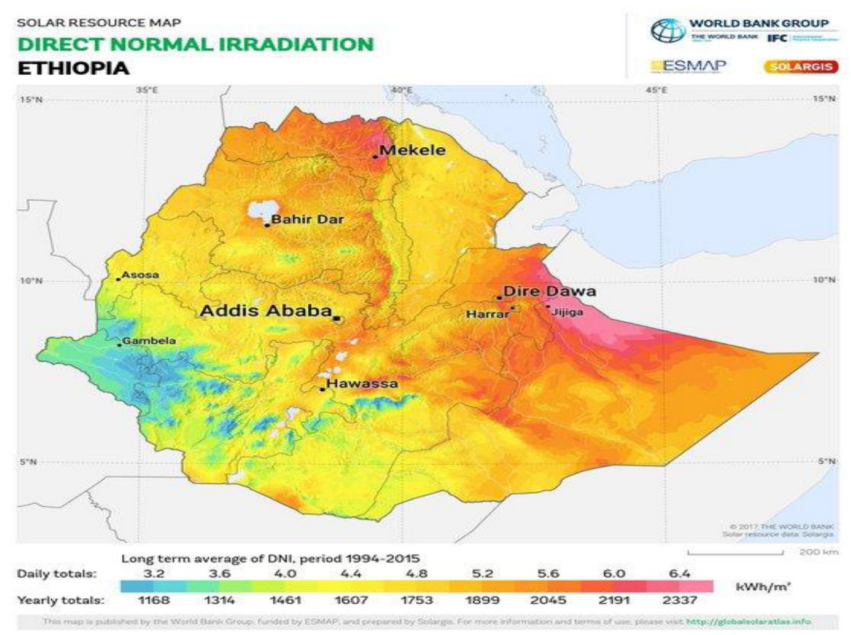

Figure 11. DNI potential of Ethiopia (reproduced with permission; copyright SOLARGIS) (GeoModel Solar). studies focusing on developing a roadmap for solar PV systems in Ethiopia (Kebede, 2017) compounded with studies done on the different types of solar energy technologies that are applicable in the rural region of Tigray, Ethiopia (TRWRDME, 2017).

There have been studies on the application of a hybrid solar PV wind system for rural communities in Ethiopia (Bekele \& Tadesse, 2012) and (Bekele \& Palm, 2010). There have also been studies on having a hybrid system for rural electrification composed of solar PV, wind, and hydro-power (Bekele \& Boneya, 2012).

\section{Wind energy}

There is significant wind energy potential in Ethiopia to be effectively utilized in the context of electricity generation. The current installed capacity of $324 \mathrm{MW}$ is a testament to the under-utilization of the wind energy potential in Ethiopia. The Danish International Development Agency has developed a framework for realizing the wind energy potential in Ethiopia in the context of improving the resource assessment of wind; government incentives and policy frameworks; wind power integration aspects; and developing a roadmap for wind energy in Ethiopia (Danida, 2016). The framework hierarchy is shown in Figure 13.

The average wind power density and wind speed for Ethiopia is shown in Figure 14. The northern, southern, and eastern locations in Ethiopia are suitable for grid integration of wind energy, as shown in Figure 15. There are a significant number of locations with energy densities greater than $400 \mathrm{~W} / \mathrm{m}^{2}$ in conjunction with wind speeds greater than $8 \mathrm{~m} / \mathrm{s}$ at $50 \mathrm{~m}$ height, as shown in Figure 14.

There have been several researches conducted in the resource mapping of wind energy, focusing primarily on the development

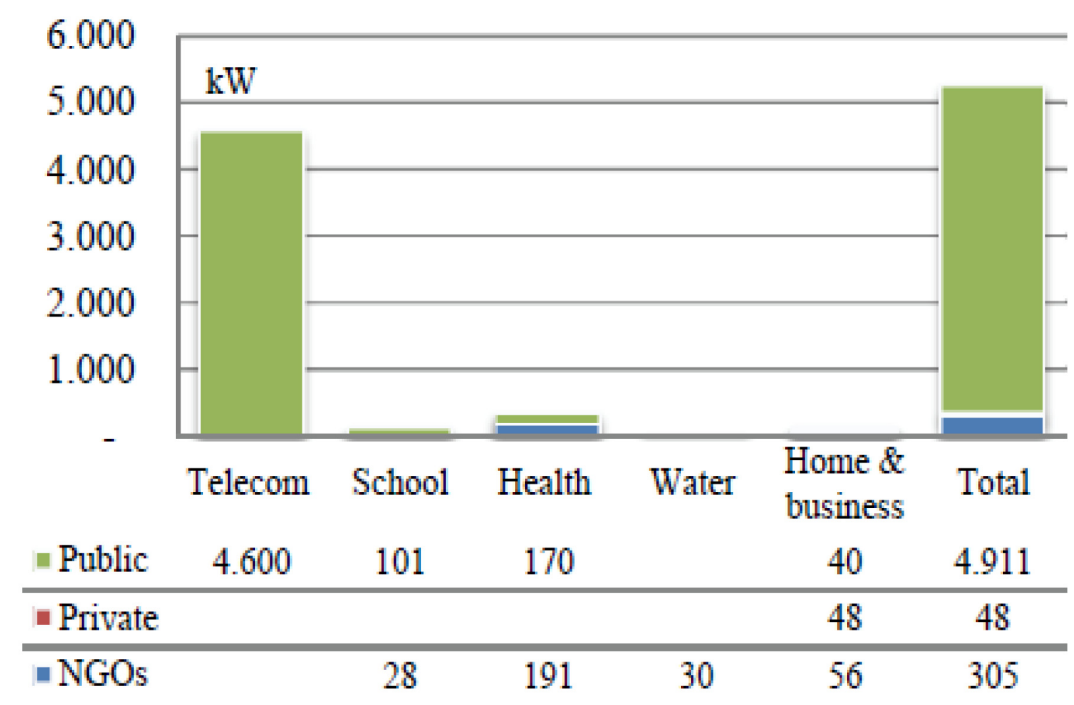

Figure 12. Solar PV capacity (reproduced with permission of ISEI, 2012). 


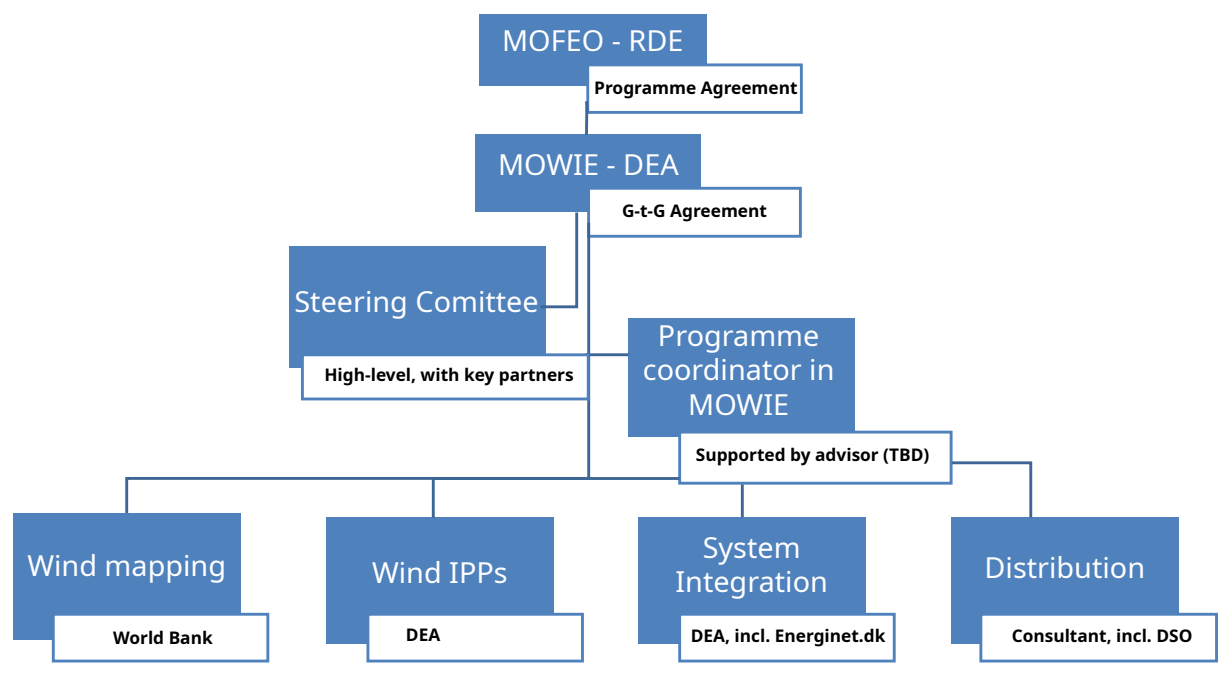

Figure 13. DANIDA framework for accelerating wind power in Ethiopia (reproduced with permission of DANIDA).

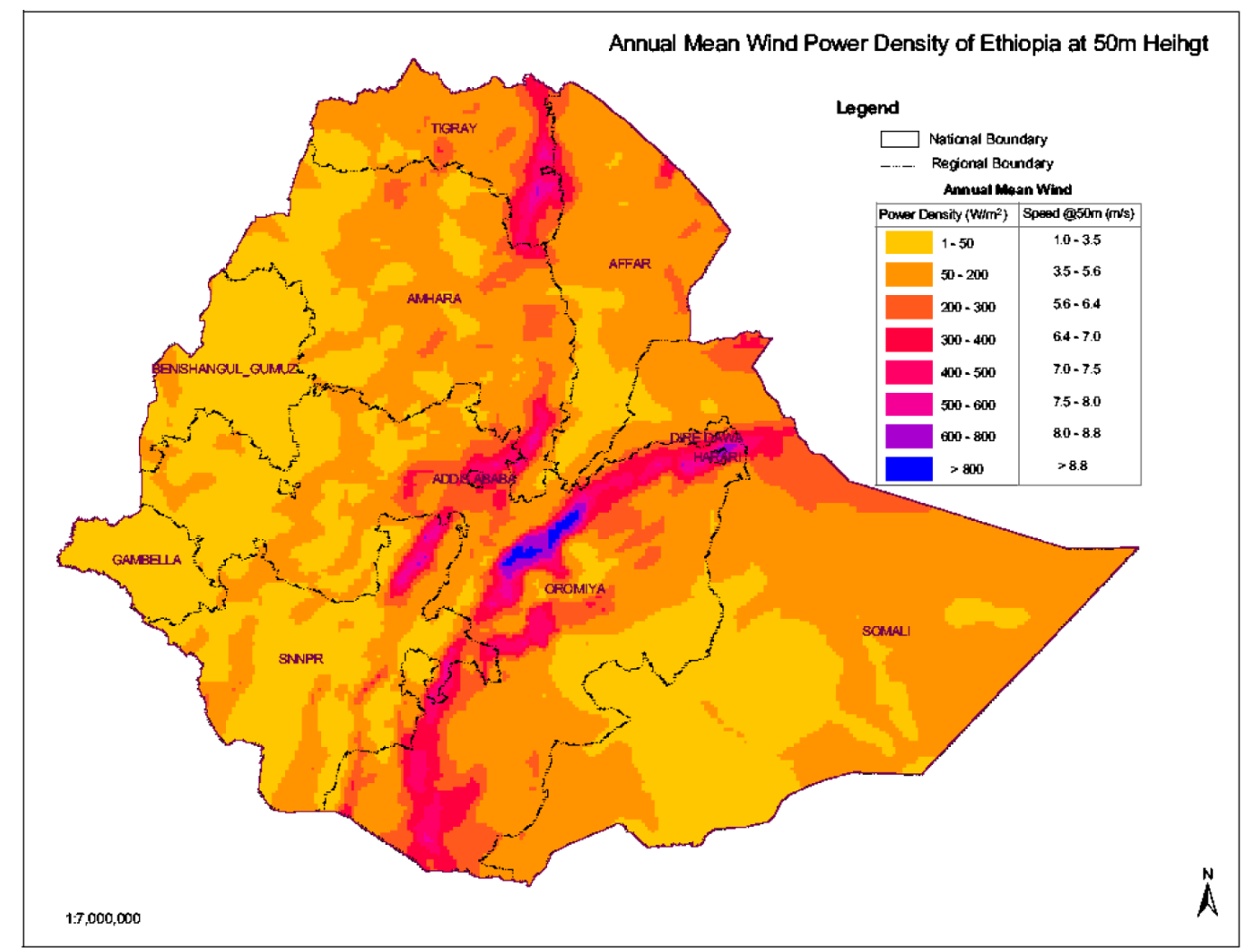

Figure 14. Average wind power density of Ethiopia (reproduced with permission of ERED, 2007).

of a wind atlas for the Geba catchment in northern Ethiopia (Bayray et al., 2013). The wind energy potential of Addis Ababa, Mekele, Nazret, and Debrezeit has been assessed to be favorable (Bekele \& Palm, 2009). There have also been studies focusing on replacing hydro power in Ethiopia with wind energy (Asress et al., 2013) compounded by researches focusing on grid integration of wind energy (Bekele \& Tadesse, 2012).

\section{Bio-energy}

There is a major reliance on bio-energy resources in Ethiopia, which is utilized in an unsustainable manner. The utilization of 


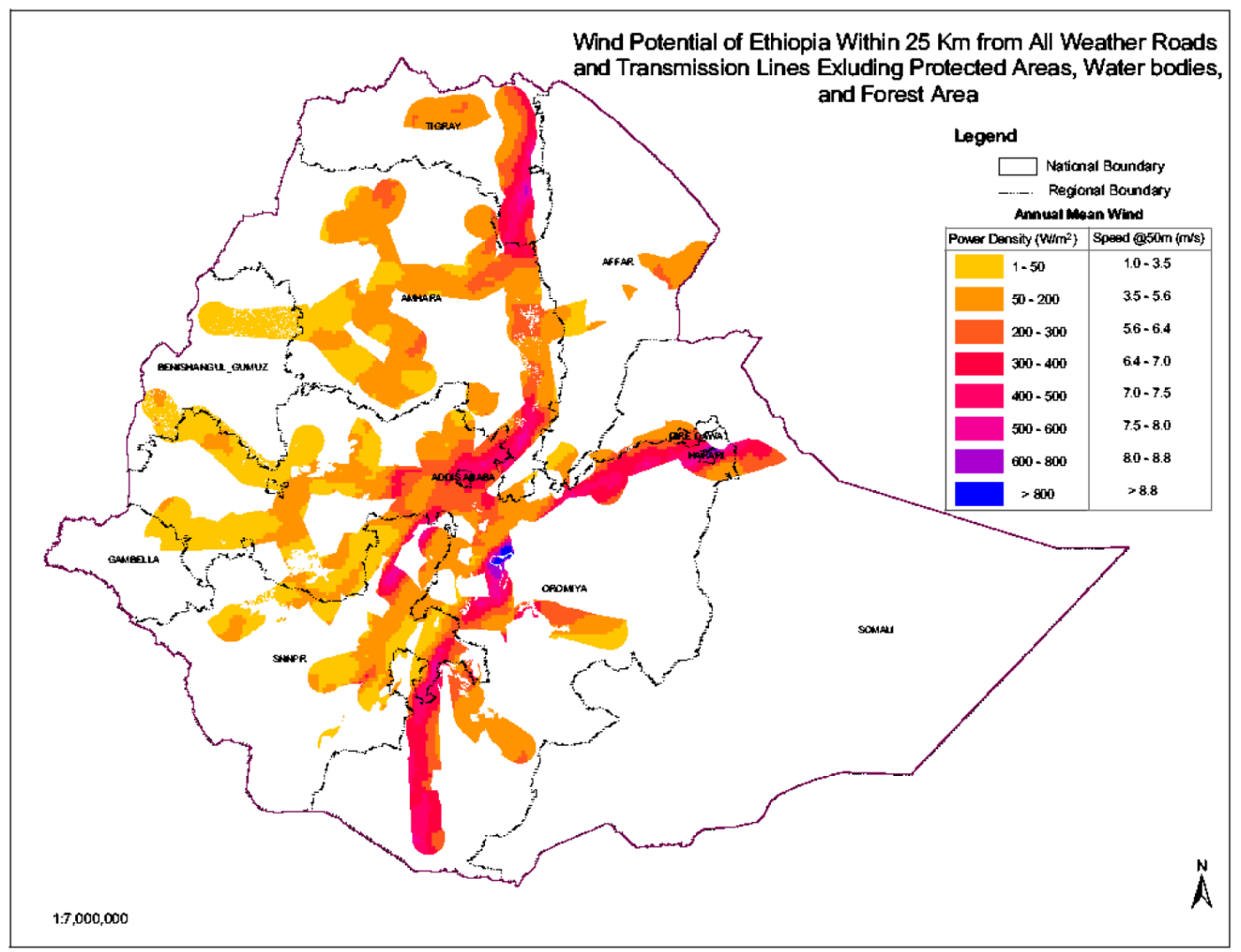

Figure 15. Suitable areas for grid integration of wind energy (reproduced with permission of ERED, 2007).

biomass fuels, which accounts for more than $90 \%$ of the energy source for the household and commercial sectors are used for thermal applications (EREDPC, 2008) (Woldegiorgis, 2002). The inability to supply affordable, efficient, and environmentally friendly bio-energy technologies has been the Achilles heel of the bio-energy sector in Ethiopia (Mengistu et al., 2016).

The majority of rural households depend on solid biomass fuels for cooking including $84 \%$ of urban households (CSA, 2012). The use of solid biomass fuels has increased from $78 \%$ in 2004 to $84 \%$ in 2011 in urban households in Ethiopia. Solid biomass fuels are the only option in rural areas, which leads to the unsustainable use of biomass. The majority of the rural households cannot afford to pay for electricity despite the relatively low electricity prices in Ethiopia. There are about 1.65 million households connected to the grid, of which $18 \%$ of those households use electricity for cooking (CSA, 2012).

There are over 10 million improved biomass cooking stoves disseminated in Ethiopia, of which firewood stoves accounts to about one half of the total disseminated cook stoves (MOWIE, 2010-2015). There are still some technical challenges in the dissemination of improved cooked stoves in the context of substandard design. There still exist over 10 million households that don't have access to improve cooked stoves and lack awareness in the importance of sustainable cooking.
Biogas technology has been promoted for cooking in rural households by the Ethiopian Government through the introduction of the National Biogas Program in 2008. There were about 8,000 domestic biogas plants installed in the year 2012/2013. The introduction of these plants has replaced about $50 \%$ of the households using conventional woody biomass. There have been incentives of constructing biogas plants in over 100 Institutions in Ethiopia. The use of biofuels have to be incentivized, as Ethiopia spends $80 \%$ of its foreign revenues earned to import petroleum for the transportation, household, and industrial sectors. There has to be an energy balance conducted for conventional and renewable fuels achieved through a comprehensive energy demand and supply modeling, which will yield a pragmatic energization plan for Ethiopia. This fact is exemplified by the households in Addis Ababa consuming about $56 \%$ of the total national consumption of kerosene in Ethiopia.

Biogas energy from animal waste is a potential area of research that Ethiopia needs to consider in its energy balance and management framework. According to the Central Statistical Agency of Ethiopia, the total cattle population in Ethiopia is estimated to be about 49.3 million. There have been researches conducted on the comprehensive review of biomass in Ethiopia (Berhanu et al., 2017) and (Guta, 2012). In addition, there have been studies focused on establishing the linkage between biogas technology adoption and the health 
status of households in rural Tigray (Abadi et al., 2017), in conjunction with research work done on assessing the domestic biogas sector in Ethiopia (Kamp \& Forn, 2016). In addition, there has been research conducted on assessing the potential sites for Jatropha production in Ethiopia using geographical information systems (GIS) (Taddese, 2016), compounded with studies focusing on the techno-economic assessment of biogas energy in rural Ethiopia (Gwavuya et al., 2012).

The proportion of biogas plants in Ethiopia that are not functional is about $60 \%$ (Eshete et al., 2006). The fixed dome and floating drum installations accounts for $68 \%$ and $16 \%$ of the installed biogas plants respectively. Studies conducted indicate that fixed dome installations are more reliable than floating drum installations (Eshete et al., 2006).

The failure on demand for the majority of the biogas plants is due to poor preventative maintenance in conjunction with substandard design and lack of trained personnel (Asres, 2012).

The potential sites for Jatropha in Ethiopia are shown in Figure 16 (Tadele, 2014).

\section{Geothermal Energy}

There are 22 locations in Ethiopia that are favorable for large scale electricity generation from geothermal energy, as shown in Figure 17 (Kebede, 2017). The geothermal energy potential of Ethiopia is over $10 \mathrm{GW}$ (Kebede, 2017). Figure 18 shows the detailed surface explorations completed up to date
(Kebede, 2017). The test well drillings of three wells in the Doubti area have recorded temperatures of $270^{\circ} \mathrm{C}$ and $250^{\circ} \mathrm{C}$ in the deep and shallow wells, respectively. The temperatures recorded are ideal for cogeneration (Kebede, 2017). There exists a 7.2 MW installed capacity geothermal power plant at Aluto Langano since 1998 (Kebede, 2017). The other locations such as Sodere, Wondo Genet, and Filhiwa are used for direct use (Kebede, 2017). However, the Aluto Langano power plant has a reduced installed capacity due to the lack of preventative maintenance.

There are plans to expand the capacity of Aluto Langano geothermal power plant to $70 \mathrm{MW}$ in 2018 (MOWIE, 2010-2015). Additionally, the first phase of the 25 MW Tandeho Alalobeda was conducted in 2017 (MOWIE, 2010-2015). The Tandeho Dubti shallow reservoir project of $12 \mathrm{MW}$ will be initiated in 2018 (MOWIE, 2010-2015). Finally, the first phase of the Corbetti project of $500 \mathrm{MW}$ will be initiated in 2018 (MOWIE, 2010-2015).

There have been notable researches conducted on geothermal exploration and development in Ethiopia (Kebede, 2012) and (Kebede, 2014) compounded with research conducted on the Aluto geothermal field (Hochstein et al., 2017). In addition, there has been geothermal exploration conducted in the northern Lake Abaya area, which has shown favorable geothermal potential (Minissale et al., 2017). In addition, there has been research conducted on developing a three-dimensional conductivity model of the Tendaho high enthalpy geothermal field in north eastern Ethiopia (Didana et al., 2015).

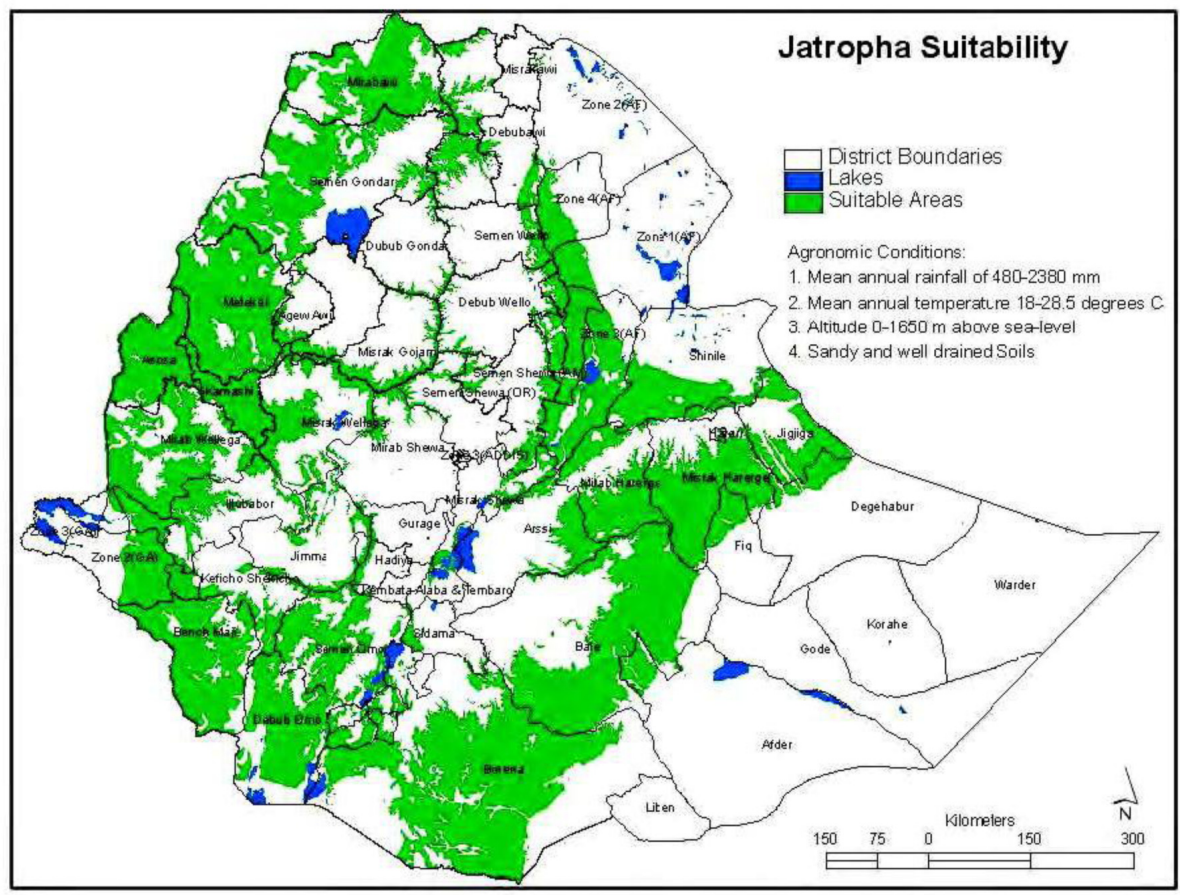

Figure 16. Jatropha suitability locations in Ethiopia (reproduced with permission of Tadele, 2014). 


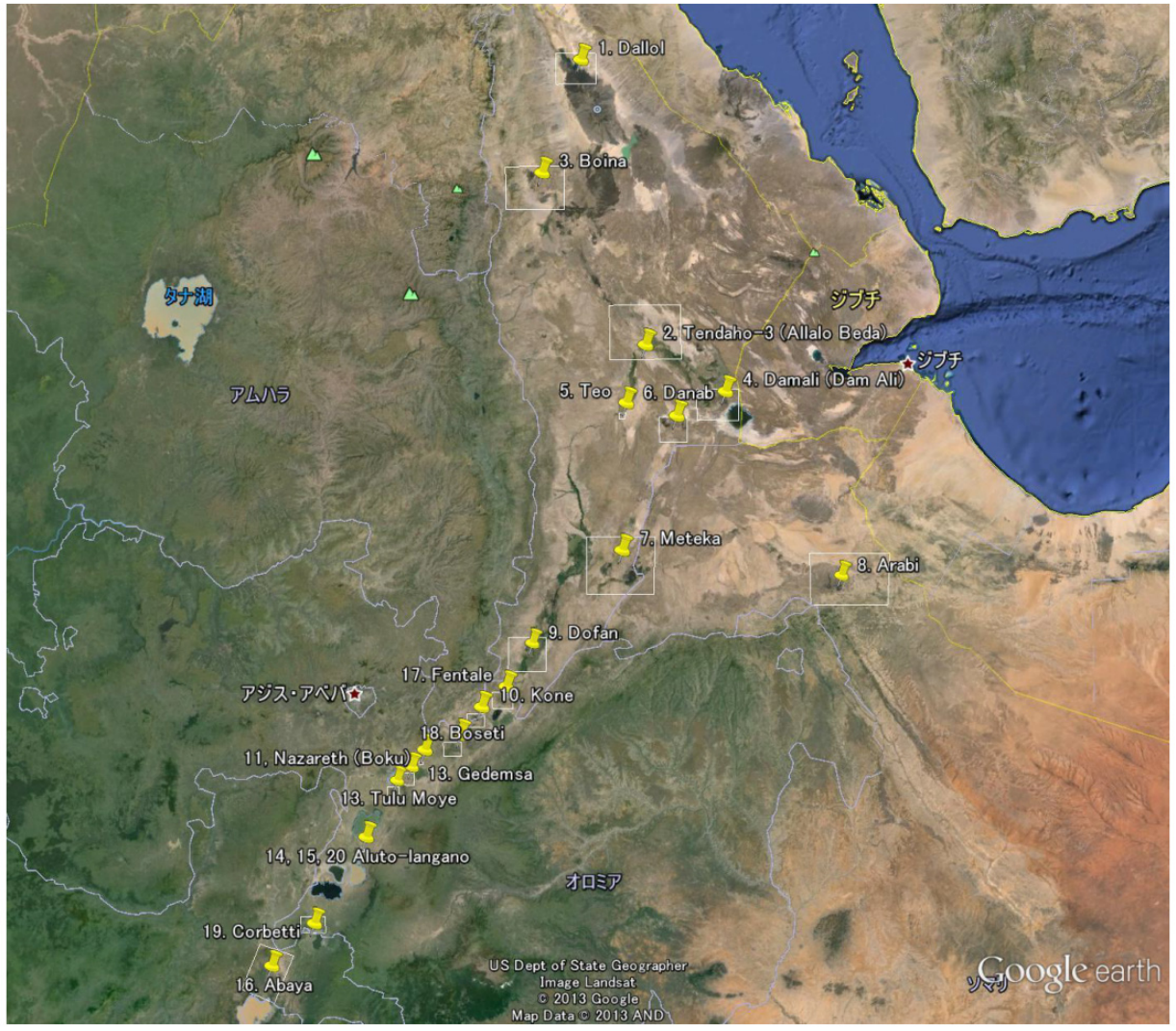

Figure 17. Geothermal potential of Ethiopia (reproduced with permission of Kebede, 2017).

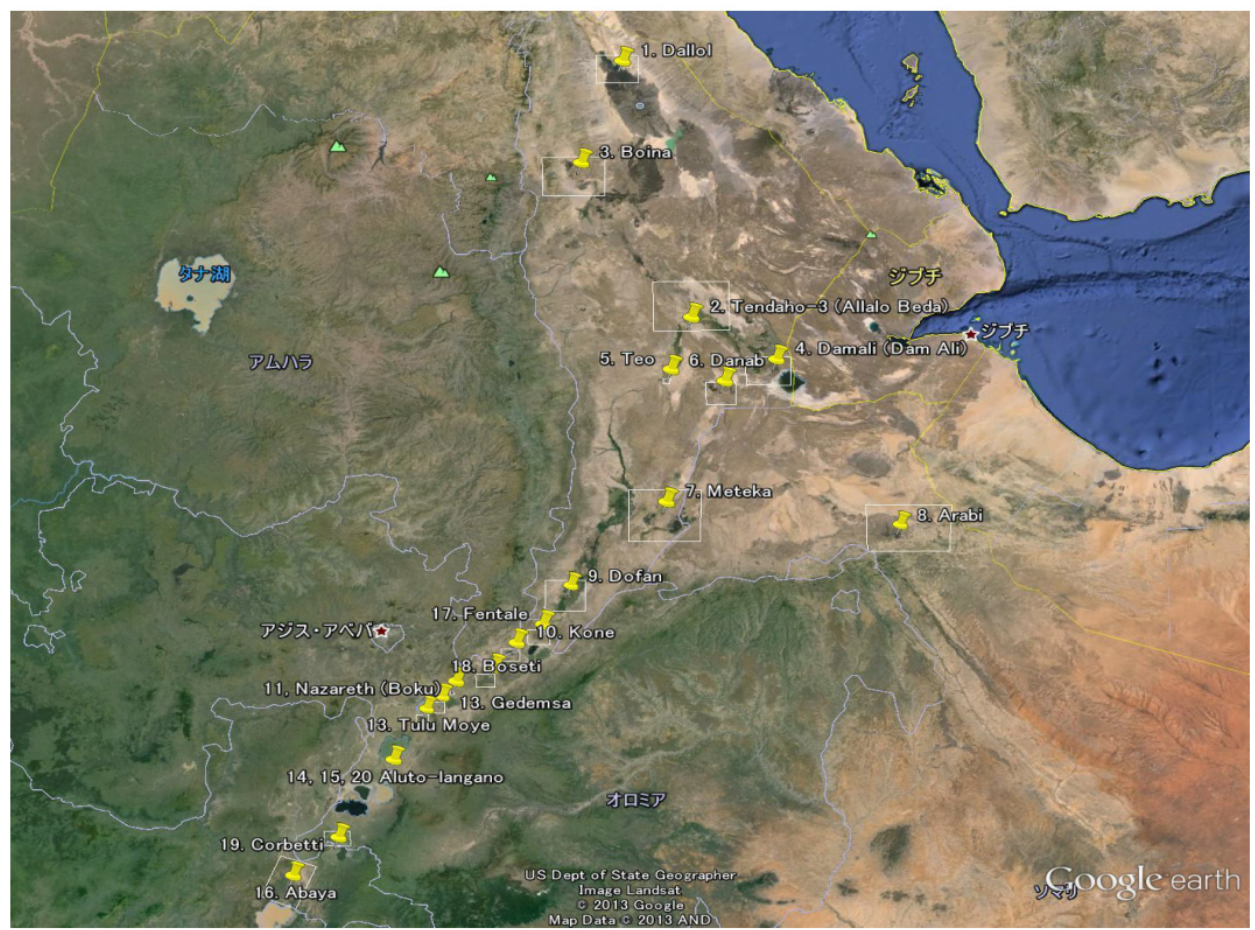

Figure 18. Geophysical exploration of the sites completed reproduced with permission of (Kebede, 2017). 


\section{Market deployment of renewable energy technologies in Ethiopia \\ Solar and wind energy}

The interplay of technical, capacity, information, economic, institutional and policy constitute as barriers with regards to the implementation of solar and wind energy technologies in Ethiopia (ERED, 2007). The implementation barriers of solar and wind energy are shown in Table 2.

The major stakeholders and the activities in the solar PV industry in Ethiopia are illustrated in Table 3 (ISEI, 2012).

\section{Geothermal energy}

Geothermal energy has been given a top priority to replace hydro power, which is prone to drought. The long-term power development is to have 2,500 MW by 2030 and 5,000 MW by 2037 (MOWIE, 2010-2015). The strategic implementation in conjunction with a comprehensive review of the geothermal sector has been conducted (MOWIE, 2010-2015).

Geothermal energy is expected to contribute $30 \%$ of the energy generated in the grid, which is approximately 40,000 GWh in tandem with having a capital cost of US\$4 million per MW (MOWIE, 2010-2015). This investment will generate US\$20 billion in 25 years (MOWIE, 2010-2015). There has been research conducted on the strengths, weakness, opportunity and threat analysis (SWOT) of geothermal energy, as shown in Table 4 (MOWIE, 2010-2015).

\section{Bioenergy}

There are several challenges identified in the biogas sector in Ethiopia, as shown in Table 5 (Kamp \& Forn, 2016). The main drivers and barrier of the biogas sector in Ethiopia are shown in Table 6 (Kamp \& Forn, 2016).

\section{Table 2. Implementation barriers of solar and wind energy technologies in Ethiopia.}

\begin{tabular}{|c|c|c|c|c|c|}
\hline Technical & Capacity & Information & Economic & Institutional & Policy \\
\hline $\begin{array}{l}\text { Lack of local } \\
\text { content } \\
\text { development }\end{array}$ & $\begin{array}{l}\text { Inadequate } \\
\text { technology } \\
\text { development }\end{array}$ & $\begin{array}{l}\text { Inadequate } \\
\text { dissemination } \\
\text { efforts }\end{array}$ & $\begin{array}{l}\text { Lack of affordability } \\
\text { due to high levels } \\
\text { of poverty reflected } \\
\text { by the low GDP per } \\
\text { capita }\end{array}$ & $\begin{array}{l}\text { Institutional inadequacies } \\
\text { at all levels in terms of } \\
\text { research facilities and } \\
\text { research outputs: patents, } \\
\text { publications in the context } \\
\text { of translating invention to } \\
\text { innovation }\end{array}$ & $\begin{array}{l}\text { The policies are } \\
\text { outdated especially } \\
\text { the Energy Policy } \\
\text { document from } \\
1994\end{array}$ \\
\hline $\begin{array}{l}\text { Lack of training } \\
\text { facilities }\end{array}$ & $\begin{array}{l}\text { Lack of technical } \\
\text { expertise in the } \\
\text { context of the } \\
\text { STEM fields }\end{array}$ & $\begin{array}{l}\text { Inadequate } \\
\text { feedback } \\
\text { mechanism }\end{array}$ & High interest rates & $\begin{array}{l}\text { Lack of a laboratory } \\
\text { inventory between various } \\
\text { Institutions }\end{array}$ & $\begin{array}{l}\text { Lack of updated } \\
\text { electricity master } \\
\text { plans }\end{array}$ \\
\hline $\begin{array}{l}\text { Lack of } \\
\text { maintenance } \\
\text { facilities }\end{array}$ & $\begin{array}{l}\text { Tripartite structure } \\
\text { of Government, } \\
\text { Academia, and } \\
\text { Industry not fully } \\
\text { realized }\end{array}$ & $\begin{array}{l}\text { Lack of } \\
\text { awareness }\end{array}$ & $\begin{array}{l}\text { High payback } \\
\text { period }\end{array}$ & $\begin{array}{l}\text { Lack of capacity building } \\
\text { programs at the various } \\
\text { Institutions }\end{array}$ & $\begin{array}{l}\text { Lack of appropriate } \\
\text { Feed-in Tariff } \\
\text { mechanisms }\end{array}$ \\
\hline $\begin{array}{l}\text { Lack of } \\
\text { standards for } \\
\text { solar and wind } \\
\text { energy }\end{array}$ & $\begin{array}{l}\text { Outsourcing and } \\
\text { brain drain }\end{array}$ & $\begin{array}{l}\text { Lack of a } \\
\text { common } \\
\text { database of data } \\
\text { for replication }\end{array}$ & $\begin{array}{l}\text { Lack of a } \\
\text { comprehensive } \\
\text { techno-economic } \\
\text { assessment }\end{array}$ & $\begin{array}{l}\text { Lack of cooperation between } \\
\text { Institutions in the context of } \\
\text { fragmented researches }\end{array}$ & $\begin{array}{l}\text { Lack of roadmaps } \\
\text { and standards } \\
\text { for solar/wind } \\
\text { technologies } \\
\text { for embedded } \\
\text { generation }\end{array}$ \\
\hline $\begin{array}{l}\text { Lack of a } \\
\text { structured } \\
\text { know-how } \\
\text { exchange }\end{array}$ & $\begin{array}{l}\text { Lack of state of the } \\
\text { art manufacturing } \\
\text { companies in } \\
\text { solar/wind }\end{array}$ & $\begin{array}{l}\text { Lack of quality } \\
\text { assurance } \\
\text { and control } \\
\text { mechanisms }\end{array}$ & $\begin{array}{l}\text { Lack of innovative } \\
\text { and cost efficient } \\
\text { technologies }\end{array}$ & $\begin{array}{l}\text { Lack of appropriate } \\
\text { technology }\end{array}$ & $\begin{array}{l}\text { Lack of an } \\
\text { energization plan }\end{array}$ \\
\hline $\begin{array}{l}\text { Lack of qualified } \\
\text { and competent } \\
\text { engineers }\end{array}$ & $\begin{array}{l}\text { Lack of solar and } \\
\text { wind test stations } \\
\text { and facilities }\end{array}$ & $\begin{array}{l}\text { Fragmented } \\
\text { coordination } \\
\text { including weak } \\
\text { linkages }\end{array}$ & $\begin{array}{l}\text { High product cost } \\
\text { due to lack of scale }\end{array}$ & $\begin{array}{l}\text { Lack of super computers } \\
\text { and advanced facilities }\end{array}$ & $\begin{array}{l}\text { Lack of } \\
\text { comprehensive } \\
\text { wind/solar resource } \\
\text { maps }\end{array}$ \\
\hline $\begin{array}{l}\text { Lack of frugal } \\
\text { engineering } \\
\text { practices }\end{array}$ & $\begin{array}{l}\text { Lack of pilot } \\
\text { projects for } \\
\text { replication }\end{array}$ & $\begin{array}{l}\text { Lack of modern } \\
\text { ICT facilities }\end{array}$ & $\begin{array}{l}\text { Substandard } \\
\text { imported products }\end{array}$ & $\begin{array}{l}\text { Lack of manufacturing of } \\
\text { solar cells and wind turbine } \\
\text { blades }\end{array}$ & $\begin{array}{l}\text { Top down approach } \\
\text { applied (energy } \\
\text { targets set without } \\
\text { conducting an } \\
\text { energy needs } \\
\text { assessment) }\end{array}$ \\
\hline
\end{tabular}




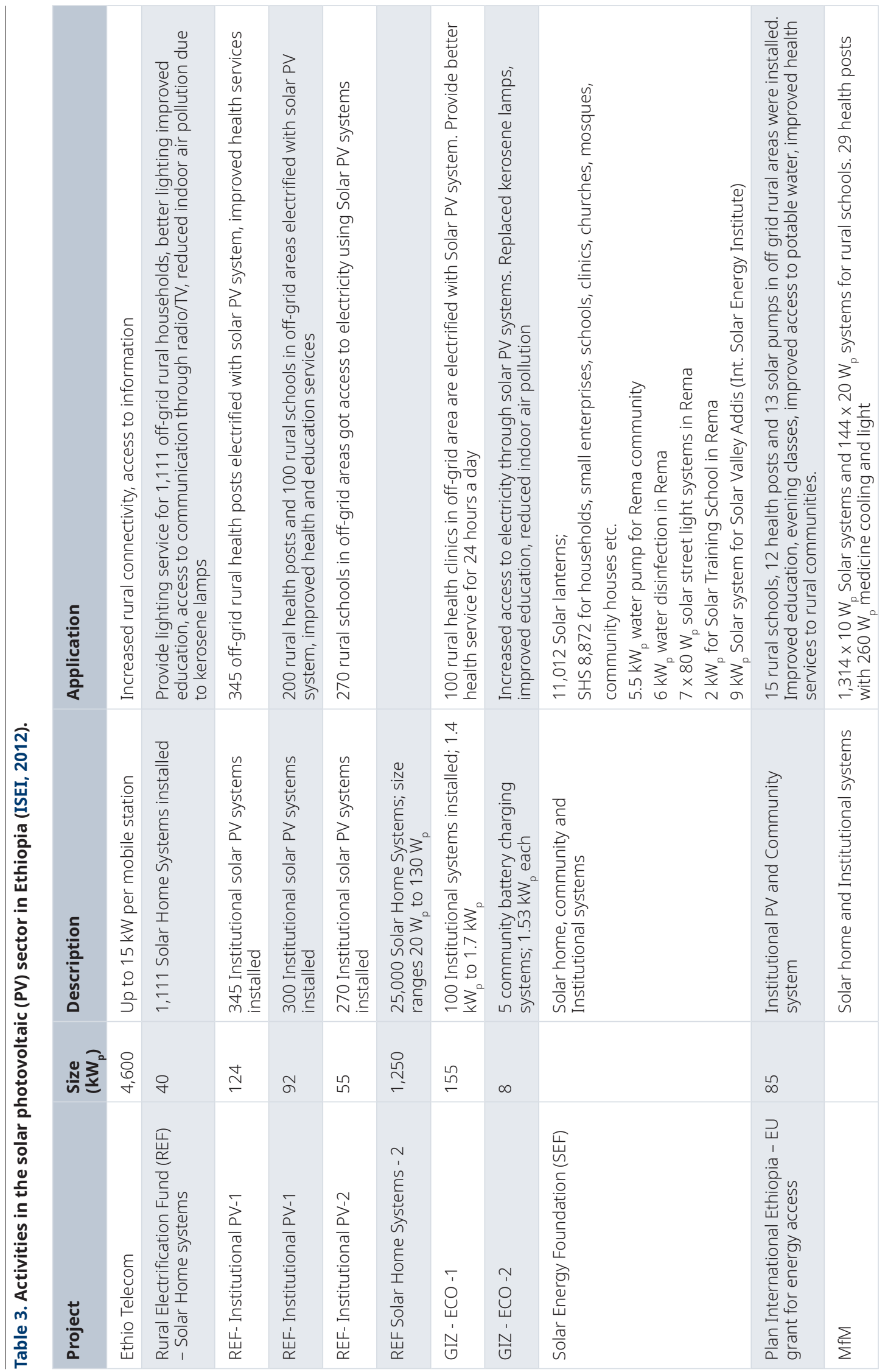




\section{Table 4. SWOT analysis of geothermal energy (MOWIE, 2010-2015).}

\section{Strengths and Opportunities}

Large resource potential based on detailed investigations and tests done/on going

Strong policy commitment (cost competitive, baseload, renewable, cogeneration, indigenous, energy security, and climate resilience)

Open for private sector development in the context of Independent Power Producers (IPP)

Adhering to SDG goals, COP 21, 22, \& 23, Agenda 2063, and Global Green Growth framework

Potential of conducting a comprehensive resource assessment and management

Generating revenue by exporting power to other African countries

\section{Challenges and Weaknesses}

Large financial requirement

Resource and other risks

Long gestation period

Lack of Institutional capacity

Shortage of professional skills (scientific, technical, commercial, and legal)

Sub optimal legal and regulatory framework (upstream mineral - downstream energy/power)

\section{Table 5. Challenges in the biogas sector in Ethiopia (Kamp \& Forn, 2016).}

\begin{tabular}{|c|c|}
\hline Category & Issue \\
\hline Technical Development & $\begin{array}{l}\text { - Domestic biogas installations cannot supply the full domestic energy demand } \\
\text { - Non-local materials increase investment costs and maintenance problems } \\
\text { - In relation with the available dung, most installations are over-sized } \\
\text { - Without proper technical back-up, any plant will fail sooner or later } \\
\text { - "Single actor construction" weakens local technical back-up facility } \\
\text { - Standardization will improve quality }\end{array}$ \\
\hline Development of the user context & $\begin{array}{l}\text { - Farmers need proper instruction to maximize the benefits from their investment } \\
\text { - Biogas installation as a "stand-alone" application are likely to fail } \\
\text { - The plant's water requirement shall not be underestimated }\end{array}$ \\
\hline $\begin{array}{l}\text { Government context and } \\
\text { regulatory framework }\end{array}$ & $\begin{array}{l}\text { - EREDPC seems the best placed lead agency for a federal domestic biogas programme } \\
\text { - The Bureaus of Energy would seem the best placed coordinating, supervising and integrating } \\
\text { agencies at regional level } \\
\text { - The extension network of the Bureaus of Agriculture would be an asset for a large scale } \\
\text { dissemination programme } \\
\text { - The regional micro-finance Institutions can play an important role in a large scale domestic } \\
\text { biogas programme }\end{array}$ \\
\hline
\end{tabular}

\section{Conclusion}

- Ethiopia has invested 100 million US Dollars in renewable energy and is by far the fifth largest investor in Africa. Ethiopia intends to become the wind capital of Africa by 2020 with an installed wind capacity of $5.2 \mathrm{GW}$. Ethiopia has also initiated large scale geothermal projects in the Corbetti and Tulu Moye areas, which will have a combined capacity of $1 \mathrm{GW}$.

- Ethiopia under the newly implemented GTP II intends to increase the current installed power capacity of $4,300 \mathrm{MW}$ to $17,000 \mathrm{MW}$ by 2020 . Ethiopia has a vast renewable potential, which is unrealized due to the lack of a comprehensive resource management and assessment.

- Ethiopia intends to transition from the unsustainable use of biomass in conjunction with replacing the dominant hydropower source with geothermal and wind. The plan is to have 5,000 MW of installed geothermal capacity by 2037 .

- There stills exists technical, capacity, economic and Institutional barriers with regards to the uptake of solar, wind, geothermal, and bio-energy technologies in Ethiopia. The problem manifests itself due to the top down approach being applied to the different 
Table 6. Drivers and barriers of the biogas sector in Ethiopia (Kamp \& Forn, 2016).

\begin{tabular}{|c|c|c|}
\hline $\begin{array}{l}\text { Socio-technical } \\
\text { level }\end{array}$ & Barriers & Drivers \\
\hline Landscape & $\begin{array}{l}\text { - } \text { Political and economic instability } \\
\text { - } \text { - Wides suitability of economic climate for enterprises and innovation } \\
\text { - } \text { - Lack of natural resources - water shortages } \\
\text { - High rate of illiteracy } \\
\text { - } \text { Presence of different tribes with different mother tongues }\end{array}$ & $\begin{array}{l}\text { - Suitability of the climate } \\
\text { - Lack of natural resources } \\
\text { - depletion of firewood }\end{array}$ \\
\hline Regime & $\begin{array}{l}\text { - Amount of lock-in regime - deeply rooted practice of injera cooking } \\
\text { which is currently not possible on biogas }\end{array}$ & $\begin{array}{l}\text { - } \text { Presence of NBPE programme } \\
\text { - } \text { Stability in regime - deeply rooted } \\
\text { - Suitability of sectoral policy } \\
\text { - Amount of lock-in regime - deeply } \\
\text { rooted practice of firewood use }\end{array}$ \\
\hline Niche & $\begin{array}{l}\text { - Not fully completeness of network of actors - private sector is missing } \\
\text { - } \text { Poor alignment in network of actors - many mismatches between } \\
\text { - Mismatch between expectations and actual development } \\
\text { - implementation goals not been reached; private sector is still not } \\
\text { involved } \\
\text { - Problems with first order learning among masons, technicians and } \\
\text { users } \\
\text { - Lack of second order learning - issues present at start of NBPE } \\
\text { programme are still not resolved }\end{array}$ & $\begin{array}{l}\text { - Presence of first order learning } \\
\text { among NBPE actors and } \\
\text { governmental actors }\end{array}$ \\
\hline
\end{tabular}

regions of Ethiopia, whereby grand targets are applied without conducting the energy needs assessment of a given region. A better approach is the utilization of the bottom up approach in conjunction with the effective articulation of the tripartite structure of Government, Academia, and Industry in order to overcome these barriers.

- Ethiopia has initiated engagement with Independent Power Producers (IPP) in the ongoing geothermal projects. However, appropriate Feed-in Tariff (FiT) topologies needs to be assessed for the different renewable energy technologies including appending the renewable energy policy document to the current energy policy document. The current energy policy document needs to have clearly defined policies for solid, liquid, and gaseous biomass fuels in order incubate a conducing environment for investors.

\section{Data availability}

All data underlying the results are available as part of the article and no additional source data are required.

\section{References}

Abadi N, Gebrehiwot K, Techane A, et al.: Links between biogas technology adoption and health status of households in rural Tigray, Northern Ethiopia. Energy Policy. 2017; 101: 284-292. Publisher Full Text

Asress $M$, Simonovic $A$, Komarov $D$, et al.: Wind energy resource development in Ethiopia as an alternative energy future beyond the dominant hydropower. Renewable and Sustainable Energy Reviews. 2013; 23: 366-378. Publisher Full Text

Asres T: Master of Science Thesis: The current status of traditional biomass energy utilization and its alternative renewable energy technology in the Amhara region of Ethiopia. 2012.

Reference Source 
Bayray M, Mustefa A, Yohannes F, et al.: Wind energy data analysis and resource mapping of Geba catchment, North Ethiopia. Wind Engineering. 2013; 37(4): 333-346.

Publisher Full Text

Bekele S: The Ethiopian power sector: a renewable future. Ministry of Water Irrigation and Electricity; Berlin Energy Transition Dialogue, 2017.

Bekele G, Boneya G: Design of a photovoltaic wind hybrid generation system for Ethiopian remote area. Energy Procedia. 2012; 14: 1760-1765. Publisher Full Text

Bekele G, Palm B: Wind energy potential assessment at four typical locations in Ethiopia. Appl Energy. 2009; 86(3): 388-396. Publisher Full Text

Bekele G, Palm B: Feasibility study for a standalone solar-wind-based hybrid energy system for application in Ethiopia. Appl Energy. 2010; 87(2): 487-495. Publisher Full Text

Bekele G, Tadesse G: Feasibility study of small Hydro/PV/Wind hybrid system for off-grid rural electrification in Ethiopia. Appl Energy. 2012; 97 5-15.

Publisher Full Text

Berhanu SM, Jabasingh A, Kifile Z: Expanding sustenance in Ethiopia based on renewable energy resources - A comprehensive review. Renewable and Sustainable Energy Reviews. 2017; 75: 1035-1045.

Publisher Full Text

Buzanakova A: International Energy Agency 2015.

Central Statistical Agency of Ethiopia Document 2012

Danish International Development Agency: Accelerating wind power generation in Ethiopia. 2016.

Reference Source

Didana Y, Theil S, Heinson G: Three dimensional conductivity model of the Tendaho high enthalpy geothermal field, NE Ethiopia. Journal of Volcanology and Geothermal Research. 2015: 290: 53-62.

Publisher Full Text

Eshete G, Sonder K, Heegde F: Report on the feasibility study of a National Program for Domestic Biogas in Ethiopia. 2006.

Reference Source

Ethiopian Rural Energy Development Promotion Centre and the Netherlands Develop Organization: National Biogas Program Ethiopia Implementation

Document. 2008.

Reference Source

Ethiopian Rural Energy Development Promotion Centre: Solar and wind energy utilization and project development scenarios. 2007.

Fuelwood-Efficient Stoves Investment Plan: Ministry of Water and Energy 2012-2015.

GeoModel Solar. Supplier by regional representative: GeoSUN Africa. Gezahegn T, Gebregiorgis G, Gebrehiwet T, et al:: Adoption of renewable energy technologies in rural Tigray, Ethiopia: an analysis of the impact of cooperatives. Energy Policy. 2018; 114: 108-113.

Publisher Full Text

Guta DD: Assessment of biomass fuel resource potential and utilization in Ethiopia: sourcing strategies for renewable energies. International Journal of Renewable Energy Research. 2012; 2(1): 132-139.

Reference Source

Gwavuya SG, Abele S, Barfuss I, et al.: Household energy economics in rural
Ethiopia: a cost-benefit analysis of biogas energy. Renewable Energy. 2012; 48: 202-209.

Publisher Full Text

Hochstein MP, Oluma B, Hole H: Early exploration of the Aluto geothermal field, Ethiopia (History of discovery well LA-3). Geothermics. 2017; 66: 73-84. Publisher Full Text

International Solar Energy Institute: Solar energy vision for Ethiopia. 2012. Reference Source

Jiangtao $\mathrm{M}$, Jianshe $\mathrm{Y}$, Kai Z, et al.: Master plan report of wind and solar energy in the Federal Democratic Republic of Ethiopia. HydroChina Beijing Engineering Corporation 2012

Kamp LM, Forn EB: Ethiopia's emerging domestic biogas sector: current status, bottlenecks and drivers. Renewable and Sustainable Energy Reviews.

2016; 60: 475-488.

Publisher Full Text

Kebede S: Status of geothermal exploration and development in Ethiopia. Geological Survey of Ethiopia 2017.

Kebede S: Geothermal exploration and development in Ethiopia: status and future plan. Geological Survey of Ethiopia 2012

Reference Source

Kebede S: Geothermal exploration and development in Ethiopia: country update. Geological Survey of Ethiopia 2014.

Reference Source

Mahmud A, Kahsay M, Hailesilasie A, et al.: Solar energy resource assessment of the Geba catchment, Northern Ethiopia. Energy Procedia. 2014; 57:

1266-1274.

Publisher Full Text

Mekonnen S: Master of Science Thesis: Solar energy assessment in Ethiopia: modeling and measurement. 2007.

Reference Sourc

Mengistu M, Simane B, Eshete G, et al:: The environmental benefits of domestic biogas technology in rural Ethiopia. Biomass and Bioenergy. 2016 90: 131-138.

Publisher Full Text

Ministry of Water Irrigation and Electricity Documents (2010-2015).

Minissale A, Corti G, Tassi F, et al.: Geothermal potential and origin of natural thermal fluids in the northern Lake Abaya area, main Ethiopian Rift,

East Africa. Journal of Volcanology and Geothermal Research. 2017; 336: 1-18. Publisher Full Text

Ministry of Water and Energy: Scaling - Up Renewable Energy Program Ethiopia Investment Plan 2012.

Tadele N: Biofuel development experience of Ethiopia. Ministry of Water Irrigation and Energy 2014

Reference Source

Taddese H: Application of Geographic Information Systems in identifying accessible sites for Jatropha curcas production in Ethiopia. Energy Procedia. 2016; 93: 82-88.

Publisher Full Text

Tigray Region Water Resource Development, Mines, and Energy Bureau: Annual Report 2017.

Reference Source

World Bank: World Development Indicators. 2014.

Reference Source

Woldegiorgis A: Overview of energy status and trends in Ethiopia. 2002. 


\section{Open Peer Review}

\section{Current Peer Review Status:}

\section{Version 1}

Reviewer Report 10 February 2021

https://doi.org/10.21956/aasopenres.14288.r28362

(C) 2021 Nazir M. This is an open access peer review report distributed under the terms of the Creative Commons Attribution License, which permits unrestricted use, distribution, and reproduction in any medium, provided the original work is properly cited.

\section{Muhammad Shahzad Nazir}

Faculty of Automation, Huaiyin Institute of Technology, Huai'an, China

I carefully evaluated your paper, founding it overall well written and well presented. The paper focuses on a relevant issue that needs to be properly investigated. The scientific background is well presented and the results are relevant. The theme is interesting and it has been analyzed in depth.

Nevertheless, a major concern has to be solved before considering your paper as suitable for indexing.

1. The Abstract may be slightly modified by adding numerical values and applied techniques.

2. The review is restricted to studies from certain geographical regions only. Is it due to the lack of sufficient studies from the regions omitted?

3. Figure 4, 5, are not providing any useful information, it can be deleted or reproduced with more details. Figure 6 and 7 are not clear.

4. Methodology and numerical values are not presented properly.

5. It is suggested to present the SWOT approach with more details for broader readability.

6. The Introduction section can be updated with the following published papers: (Nazir et al., 2020a ${ }^{1}$, Nazir et al., $2019^{2}$ and Nazir et al., 2020b³).

7. Inclusion/exclusion section should be added for comprehensive review.

The methods section is mandatory for a review article, as clearly reported in the authors instruction of the Journal. In the methods section, the authors must describe how the review has been performed (scientific databases screened, paper collection and assessment, number of included-excluded paper, inclusion and exclusion criteria, search string, keywords and so on). I suggest to follow AAS guidelines, in order to prepare a valuable method section for your review 
paper.

\section{References}

1. Nazir M, Abdalla A, Wang Y, Chu Z, et al.: Optimization configuration of energy storage capacity based on the microgrid reliable output power. Journal of Energy Storage. 2020; 32. Publisher Full Text

2. Nazir MS, Mahdi AJ, Bilal M, Sohail HM, et al.: Environmental impact and pollution-related challenges of renewable wind energy paradigm - A review.Sci Total Environ. 2019; 683: 436-444

PubMed Abstract | Publisher Full Text

3. Nazir MS, Ali ZM, Bilal M, Sohail HM, et al.: Environmental impacts and risk factors of renewable energy paradigm-a review.Environ Sci Pollut Res Int. 2020; 27 (27): 33516-33526 PubMed Abstract |

Publisher Full Text

Is the topic of the review discussed comprehensively in the context of the current literature?

Partly

Are all factual statements correct and adequately supported by citations?

Partly

Is the review written in accessible language?

Partly

Are the conclusions drawn appropriate in the context of the current research literature? Partly

Competing Interests: No competing interests were disclosed.

Reviewer Expertise: Renewable Energy

I confirm that I have read this submission and believe that I have an appropriate level of expertise to confirm that it is of an acceptable scientific standard, however I have significant reservations, as outlined above.

Reviewer Report 04 February 2021

https://doi.org/10.21956/aasopenres.14288.r28359

(C) 2021 Alemzero D. This is an open access peer review report distributed under the terms of the Creative Commons Attribution License, which permits unrestricted use, distribution, and reproduction in any medium, provided the original work is properly cited.

\section{David Ajene Alemzero}

School of Finance and Economics, Jiangsu University, Zhenjiang, Jiangsu, China

The article provides a comprehensive review of the renewables resource Ethiopia is endowed with 
and the attempts to exploit them for sustainable energy consumption.

All factual statements were correctly stated. And the English language was satisfactory. The conclusions arrived at during the research are apt.

However, the third sentence of the abstract, "jettisoning' is inappropriately used. The first of the final two sentences of the abstract has a plural noun "needs" but with a singular article "a".

Also, beneath table 6. Independent power producers (IPPs), not IPP.

Similarly, the last paragraph of the introduction. Geothermal Projects instead of a project. Because the singular noun follows a plural noun "areas."

Is the topic of the review discussed comprehensively in the context of the current literature?

Yes

Are all factual statements correct and adequately supported by citations?

Yes

Is the review written in accessible language?

Yes

Are the conclusions drawn appropriate in the context of the current research literature? Yes

Competing Interests: No competing interests were disclosed.

Reviewer Expertise: Renewables; Wind energy, Low carbon economy, Energy security, Regional Expert, Africa.

I confirm that I have read this submission and believe that I have an appropriate level of expertise to confirm that it is of an acceptable scientific standard. 